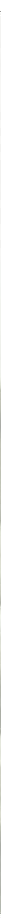

Bakgrunn: Hvert år opplever rundt 4000 barn i Norge å bli pårørende når en i nær familie, ofte mor eller far, får kreft. Kreftsykdom hos en av foreldrene kan være en påkjenning for barn og ungdom ved trusselen om tap og ved de endringer i familiens roller og hverdagsliv som følger med sykdom og behandling. Fra januar 2010 er barns selvstendige rett til informasjon styrket gjennom endringer i Helsepersonelloven.

Hensikt: Målet med denne litteraturstudien er å gjennomgå eksis- terende forskning som utdyper og konkretiserer barns og ungdoms informasjonsbehov når mor eller far får kreft.

Metode: Det ble søkt systematisk etter relevant forskningslitteratur i følgende kilder; Joanna Briggs Institute, Evidence Based Nursing, Psyclnfo, Medline, Cinahl og Svemed+.

Resultat: Til sammen ble 11 enkeltstudier og en oversiktsartikkel inkludert. Studiene synliggjør informasjonsbehovet hos barn og ungdom innenfor seks områder; barnets forståelse, informasjonens innhold, omfang, timing, informasjonskilder og gjensidig beskyttelse.

Konklusjon: Studiene viser at foreldrene er barnas viktigste informasjonskilde. Barn ønsker ærlig og konkret informasjon om sykdom og behandling, inklusiv prognostisk informasjon. Resultatene korresponderer med de nye lovbestemmelsene og føringene som gis i tilhørende rundskriv.
Children's and adolescents' information needs when mum or dad develops cancer - a review of the literature

Background: Every year, about 4,000 children in Norway experiences a family member, often one of the parents, developing cancer. Cancer in a parent can be stressful for children and youngsters because of the threat of loss and changes in family roles and everyday life following the disease and treatment. From January 2010, children's independent right to receive information is strengthened by changes in the Norwegian
Regulations for Health Personnel.

Objective: The aim of this study is to review existing research that elaborates and specifies children's and adolescents' information needs when mum or dad develops cancer.

Methods: A systematic search for relevant research literature was conducted in the following databases; Joanna Briggs Institute, Evidence-Based Nursing, Psyclnfo, Medline, Cinahl and Svemed+.

Results: A total of eleven single studies and one review article was included. The studies highlight the information needs of children and youth within six domains; the child's understanding, the content, timing and extent of the information, sources of information and mutual protection.

Conclusion: The studies suggest that the parents are children's most important source of information. Children want honest and specific information about the disease and treatment, including prognostic information. The results correspond with the new regulations and guidelines provided.

Key words: Neoplasms, child, adolescent, information, communication. 


\section{Barns og ungdoms informasjonsbehov når mor eller far får kreft}

Forfattere: Berit Hofset Larsen og Monica Wammen Nortvedt

\author{
NøKKELORD \\ - Kreft \\ - Barn \\ - Ungdom \\ - Pårørende \\ - Informasjon
}

\section{INTRODUKSJON}

Ifølge kreftforeningen opplever rundt 4000 barn under 18 år i Norge hvert år at en i nær familie får kreft (1). I mange av tilfellene er det en av foreldrene som blir syk. Selv om stadig flere blir friske, eller lever lenge med sin sykdom, er en usikkerhet kommet inn i familiens og barnets verden. Behandlingen kan være langvarig og plagsom, og dessuten innebære perioder med atskillelse på grunn av sykehusinnleggelser. Barn lever i et tett avhengighetsforhold til sine foreldre. Kreftsykdom hos mor eller far kan skape psykososialt stress hos barn og ungdom på grunn av frykt for å miste den som er syk (2), og de endringer i familiens roller, samhandling og hverdagsliv som sykdom og behandling medfører $(2,3)$. Tid- ligere studier har vist at barn i en slik situasjon opplever et økt omsorgsbehov samtidig som de voksnes omsorgsevne reduseres (4). Ifølge Benner \& Wrubel er det å gi og motta omsorg, det som gir tilværelsen mening. De beskriver stress som sammenbrudd i mening, forståelse og normal funksjon (5). Barnets mestringsevne er ifølge deres teori blant annet knyttet til muligheten for å opparbeide ny forståelse. Mye tyder på at informasjon kan redusere stress, og gi økt opplevelse av mestring og kontroll $(6,7)$. De siste årene har det vært et økende fokus på at også barna har behov for informasjon når en nær voksen får kreft. I praksis viser det seg at både foreldre og helsepersonell strever med hvordan man skal møte dette behovet. Mange ønsker råd og veiledning av helsepersonell om hvordan de skal snakke med barna og ungdommene sine (3). Tilbudet som gis til disse familiene i dag kan være fragmentert, og i liten grad satt $i$ system (1). Barns opplevelse av trygghet, tilfredshet og tilstrekkelig omsorg er sterkt knyttet til foreldrenes livssituasjon. Ifølge Helse- og omsorgsdepartemen- tet må målet være at foreldrene selv, uavhengig av helsetilstand og så langt det lar seg gjøre, ivaretar omsorgen for sine barn og at helsetjenesten bidrar til dette (8).

Fra januar 2010 har barn i Norge fått en styrket rettsstilling som pårørende. Helsepersonelloven ny $\$ 10$ a lyder; «Helsepersonell skal bidra til å ivareta det behovet for informasjon og nød-

Hva tilfører denne artikkelen? Artikkelen viser at barn av kreftpasienter har behov for ærlig og konkret informasjon om foreldrenes sykdom og konsekvenser, og at det beste er om informasjonen blir gitt av foreldrene.

\section{Mer om forfatter:}

Berit Hofset Larsen er klinisk spesialist i sykepleie med videreutdanning i kreftsykepleie. Hun er ansatt som spesialsykepleier med fagansvar, Oslo Universitetssykehus, Radiumhospitalet og leder i Forum for barn og ungdom som pårørende OUS, Rikshospitalet-Radiumhospitalet. Monica Wammen Nortvedt er intensivsykepleier, professor og leder Senter for Kunnskapsbasert praksis, Høgskolen i Bergen. Kontakt: berit.hofset.larsend oslo-universitetssykehus. 
vendig oppfølging som mindreårige barn av pasient med psykisk sykdom, rusmiddelavhengighet eller alvorlig somatisk sykdom eller skade kan ha som følge av foreldrenes tilstand»(1). Den som yter helsehjelp skal søke å avklare om pasienten har mindreårige barn, samtale med pasienten om barnets behov for informasjon eller oppfølging og tilby informasjon og veiledning. I mai 2010 ga Helsedirektoratet ut et rundskriv som omhandler de nye lovbestemmelsene og gir utfyllende kommentarer til hvordan disse skal iverksettes (9). Hensikten med denne litteraturstudien er å styrke helsepersonells handlingskompetanse innen dette området slik at de kan bistå foreldre i å ivareta omsorgen for sine barn. Vi ønsker også å diskutere om Helsedirektoratets anbefalinger i rundskrivet er i tråd med nyere forskning.

Målet med denne litteraturstudien er å gjennomgå eksisterende forskning som utdyper og konkretiserer barns og ungdoms informasjonsbehov når mor eller far får kreft.

\section{METODE}

Litteratursøk ble gjennomført i februar 2010 etter forskning som beskriver barns og ungdoms informasjonsbehov ved kreftsykdom hos mor eller far, først og fremst ut fra barnets perspektiv, men også fra foreldrenes. Søkene ble gjort i følgende databaser; Joanna Briggs Institute, Evidence Based Nursing, PsycInfo, Medline, Svemed+ og Cinahl. Denne problemstilling etterspør pasient og pårørendes opplevelse og vil derfor i utgangspunktet best kunne besvares ved kvalitative studier. Søket ble imidlertid ikke begrenset til type studie. Det var ønskelig å inkludere mest mulig oppsummert forskning i tillegg til aktuelle enkeltstudier.

Det ble tilstrebet så lik fremgangsmåte som mulig i de ulike databasene, og følgende emneord ble benyttet; neoplasms, child, adolescent, communication, patient education/client education og information. Hvert emneord ble søkt for seg, og siden kombinert på følgende måte; (exp Communication/) or (exp Patient Education as Topic/)/(exp Client Education/) or (patient education*.mp) or (information*.mp). Søkesettet ble så kombinert med resultatlisten fra exp Neoplasms/ med bindeordet "AND" for å spisse og målrette søket. I Medline ble søket i tillegg kombinert med emneordet exp Parent-Child-Relations/ med bindeordet «AND». Til slutt ble søket begrenset til aldersgruppen 0-18 år. I Svemed+ ble emneordet «Child of Impaired Parents» inkludert i søket. I Joanna Briggs Institute ble tekstordene cancer, communication og children\&youth brukt og kombinert på denne måten; LSU (\{CANCER\}) AND (LSU (\{CHILDREN \& YOUTH $\}$ ) AND LSU (\{COMMUNICA-
TION\}). Tilsvarende søkestrategi ble valgt i Evidence Based Nursing. Søket ble begrenset til skandinavisk og engelskspråklig litteratur. Vi begrenset søket til studier publisert etter 1998 for å fokusere på nyere forskning. Søket ble kvalitetssikret av bibliotekar ved Oslo Universitetssykehus, Radiumhospitalet.

Titlene og sammendragene ble lest og vurdert i forhold til relevans av førsteforfatter. Kriteriene for utvelgelsen av artiklene var at de omhandlet informasjon til barn og ungdom opp til 18 år om kreftsykdom hos en av foreldrene.

Forskning på mindreårige har alltid etiske implikasjoner (10), og særlig når barna er i en sårbar livssituasjon. I de inkluderte studiene er dette tatt hensyn til ved at det er innhentet samtykke fra foreldre og barn.

\section{RESULTAT}

Resultatene fra litteratursøket er fremstilt i tabell 1.

Til sammen ble 11 enkeltstudier og en oversiktsartikkel inkludert. Alle studiene hadde kvalitativt studiedesign. De fleste brukte semistrukturerte individuelle intervjuer som datainnsamlingsmetode (se tabell 2).

\begin{tabular}{llll}
\hline \multicolumn{3}{c}{ TABELL 1: Oversikt over antall treff } & etter litteraturs $\varnothing \mathrm{k}$ \\
\hline $\begin{array}{l}\text { Database/ } \\
\text { Tidsskrift }\end{array}$ & Antall treff & $\begin{array}{l}\text { Antall leste } \\
\text { sammendrag }\end{array}$ & $\begin{array}{l}\text { Antall } \\
\text { inkluderte }\end{array}$ \\
Joanna Briggs & 2 & 0 & 0 \\
Medline & 120 & 28 & 5 \\
Psyclnfo & $43(0-12$ år) & 5 & 3 \\
& $42(13-17 a ̊ r)$ & 7 & 3 \\
Cinahl & $132(6-12$ ar $)$ & 18 & 1 \\
& $167(13-18)$ & 9 & 2 \\
Swemed + & 11 & 5 & 1 \\
Evidence Based Nursing & 126 & 2 & 1 \\
\hline
\end{tabular}


En studie brukte i tillegg fokusgruppeintervju (18), en brukte spørreskjema og fokusgrupper (16), og en lot barna velge om de ville intervjues individuelt eller sammen med søsken (20). I to av studiene var den syke forelderen eneste informasjonskilde (21, 22). Fem av studiene hadde kun intervjuet barna (11, $14,16,18,20)$, og fire hadde intervjuet både foreldre og barn $(12,13,15,17)$. I to av studiene ble både den syke og den friske forelderen intervjuet (13, $15)$, mens en studie kun hadde intervjuet den friske (12). Antall intervjuede varierte fra 7-68. Oversiktsartikkelen (19) oppsummerer 52 enkeltstudier om hvordan kreftsykdom hos en av

TABELL 2: Inkluderte artikler

\section{Forfatter/}

Publikasjonsår

Finch A, Gibson F. (2009) (11)

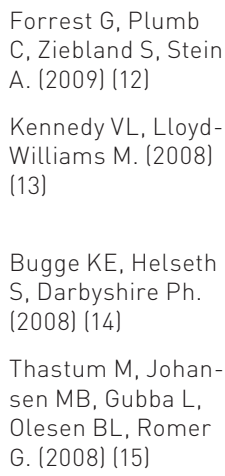

Bugge KE, Helseth S, Darbyshire Ph. (2008) (14)

Thastum M, Johansen MB, Gubba L.

Olesen BL, Romer

G. (2008) (15)

Ensby T, Dyregrov $\mathrm{K}$, Landmark B. (2008) (16)

Forrest G, Plumb

C. Ziebland S, Stein

Kristjanson LJ

Woodgate R.(2004)

(18)

Visser A, Huizinga $G A$, van der Graaf WTA, Hoekstra HJ Hoekstra-Weebers JEHM. (2004) (19)

Hilton A, Gustavson K. (2002)(20)
A. (2006)(17)

Chalmers KI,

Land

England Kvalitativ

England

Danmark

England

Neder-

Lewis FM, Zahlis

EH.(2000) (21)

Barnes J, Kroll L, Bruke 0, Lee J,

Jones A, Stein A. (2000) (22)
England

Studiedesign

Kvalitativ

Fortolkende

Fenomenologisk

Kvalitativ

Kvalitativ

Norge

Kvalitativ

Norge

Kvantitativ

Kvalitativ

Fortolkende

fenomenologisk

Kvalitativ

Canada

Kvalitativ

land

Oversikts-

artikkel

Kvalitativ

Canada

Kvalitativ

beskrivende

\section{Datasamling}

Semistrukturerte

intervjuer individuelt

Semistrukturerte intervjuer individuelt

Semistrukturerte intervjuer individuelt

Dybdeintervjuer individuelt

Semistrukturerte intervjuer individuelt

Spørreskjema

Fokusgrupper

Semistrukturerte intervjuer individuelt

Semistrukturerte Intervjuer (27) Fokusgrupper (8)

Litteraturstudie

Semistrukturerte intervjuer individuelt eller søsken sammen

Semistrukturerte intervjuer

\section{England Kvalitativ}

Semistrukturerte
Datastørrelse

7

Tenåringsbarn, 14-18 år. av kreftpasienter, 4-12 mnd etter diagnose

57 Fedre hvis partner har nydiagnostisert brystkreft(26) og deres barn, 6-18 år (31)

Barn, over 7 år, av pasienter med avansert kreft (11) den syke forelderen (10), den friske forelderen (7)

12

Barn, 6-16 år, av pasienter med uhelbredelig kreft

21+ Foreldre med kreft, ulike (9 fam) sykdomsfaser, den friske forelderen og deres barn, 8-15 år, (21)

78 Barn av foreldre med kreft

$11 \quad$ (58) eller som hadde mistet en forelder i kreft(20). 6-18 år. 42 J/36 G.

68 Mødre med nydiagnostisert brystkreft (37) og deres barn, 6-18 år, (31)

31 Tenåringsbarn, 12-20 år, av kvinner med brystkreft i ulike sykdomsfaser

52 Studier publisert jan 1980studier mars2004 som omhandler emosjonell, sosial, adferd, kognitiv og fysisk funksjon hos barn av foreldre diagnostisert med kreft

11 Barn, 7-21 år, av kvinner med brystkreft behandlet med kjemoterapi siste 2 år

19 Mødre med brystkreft med til sammen 30 barn i skolealder. 7-12 år intervjuer individuelt
Mødre med brystkreft med til sammen 56 barn i skolealder. median alder 12 år 
foreldrene innvirker på barna og familien. Studiene hadde ulike forskningsdesign og fokus. Ikke alle handlet primært om barnas informasjonsbehov, men vi fant allikevel at artikkelen hadde verdifulle bidrag til vårt spørsmål. Fire av enkeltstudiene var inkludert i oversiktsartikkelen. Vi har valgt å inkludere dem også fordi de gir utdypende informasjon. De fleste studiene er gjort på barn av brystkreftpasienter.

I det følgende vil vi presentere resultatene fra studiene ut fra seks aspekter ved barns informasjonsbehov. Ut ifra de inkluderte studiene syntes disse aspektene å være av særlig betydning; barnets forståelse, informasjonens innhold, omfang, timing, informasjonskilder og gjensidig beskyttelse.

\section{BARNS}

\section{INFORMASJONSBEHOV \\ Barnets forståelse}

Det varierte hvor mye barna hadde fått med seg av den syke forelderens situasjon, men mange hadde mistanke om at noe var alvorlig galt før de ble fortalt om sykdommen $(17,20$, 22). Barn i alle aldre var gode til å observere endringer i forelderens helse $(17,22)$ og til å trekke mens livstruende natur $(11,17$, 20,21). En del av forestillingene barna hadde var likevel uriktige eller preget av misforståelser (17). Informasjonen barna fikk var tidvis mangelfull. Noen ganger ble informasjonen formidlet på en lite hensiktsmessig måte, for eksempel når barnet var helt uforberedt $(15,17,19)$.

Barnas forståelse og reaksjoner hang sammen med alder og modenhet (19), tidligere erfaringer (21), hva andre fortalte dem og hvordan, hva de leste og hørte og hvilke ord som ble brukt $(19,20)$. Ord som leukemi, klump eller tumor ble for eksempel ikke nødvendigvis assosiert med kreft $(11,17)$. Tenåringer var ofte mer oppmerksomme på konsekvensene av sykdom og behandling enn yngre barn (19). Barnets oppfatning av sykdommens alvorlighetsgrad, belastning og prognose så ut til å ha større innvirkning på barnas emosjonelle problemer enn objektive sykdomskarakteristikker (19).

\section{Informasjonens innhold}

Alle studiene viste at noe av det barna var mest opptatt av var om forelderen kom til å overleve. Mange ønsket prog-

\section{Barn onsker å bli involvert ifra starten når det skjer endringer}

slutninger om begge foreldrenes emosjonelle tilstand ut fra endringer i atferd, kroppsholdning, ansiktsuttrykk og atmosfæren i hjemmet $(15,22)$. Ved manglende informasjon konstruerte barna sine egne forklaringer (17). Mange hadde mer forkunnskaper om kreft enn foreldrene var klar over (17), og de var ofte oppmerksom på kreftsykdom- nostisk informasjon selv om det kunne gjøre vondt (14, 17, 18). Flere hadde konkrete spørsmål om døden, som når det kunne inntreffe og om det kunne skje plutselig $(13,14)$. De fleste ønsket ærlig og konkret informasjon om forelderens sykdom og behandling $(12,13,14$, $15,17,19)$. De ønsket å få vite om bivirkninger og forventede endringer i den sykes utseende, humør, energinivå og atferd slik at de var forberedt $(12,13,14$, 18). Svært detaljert informasjon på cellenivå kunne være vanskelig for de minste å forstå (17). Mange var forvirret når det gjaldt årsaken til sykdommen $(14,19,20)$. Små barn kunne tro at kreft var smittsomt (14), mens andre var bekymret for egen helserisiko på grunn av arvelighet $(13,14,18)$.

Barna ønsket å vite hva de kunne vente seg og hva som ville skje med dem og familien (14, 16). Små barn opplevde atskillelse som følge av hospitalisering særlig belastende $(15,17)$. Enkelte var engstelige for besøk på sykehuset $(11,14)$, og noen ble skremt av sterke inntrykk som synet av blod eller medisinsk utstyr (17). Mange mente det kunne hjelpe hvis de var forberedt $(12,17)$.

Noen barn var bekymret for hvordan sykdommen skulle påvirke foreldrenes evne til å fortsette sine familieroller (11, 18, 19). Mange opplevde tap av normale aktiviteter og redusert kontakt med jevnaldrende som en belastning (19). Det var ikke uvanlig at barna hadde skyldfølelse for manglende innlevelse og ønske om å fortsette sitt eget liv (19). Noen kunne også føle ansvar for kreftsykdommen og humørforandringer hos foreldrene $(18,19)$. En del hadde vanskelig for å forstå seg selv, og opplevde det som god hjelp å få kunnskap om egne reaksjoner, mestringsmuligheter $(14,18)$ og tilgjengelig støtte $(13,14,16)$. Noen tenåringer understreket viktigheten av håp uansett alvorligheten av sykdommen (18). En del satte også pris på informasjon om hva som var forventet av dem, og hvordan de kunne hjelpe $(14,18)$. 


\section{Informasjonens omfang}

$\AA$ bestemme hvor mye man skulle si til barna, var vanskelig for mange foreldre $(12,17,19$, 21, 22). Manglende informasjon kunne føre til misforståelser og bekymring $(17,19,21)$, mens for stor informasjonsmengde kunne bidra til forvirring, særlig hvis den ikke var tilpasset barnets modenhet $(15,20,21)$. Generelt kunne det se ut som barns ønske om informasjon økte med stigende alder (17). Noen ønsket full åpenhet (15). Andre prøvde å begrense informasjonsmengden, og ville at foreldrene skulle sile informasjonen for dem (13, 21).

\section{Timing}

Behovet for informasjon varierte med ulike faser av sykdommen (13). De aller fleste ønsket å bli inkludert fra starten $(12,14,15$, 17, 22). Mange opplevde behovet størst rett etter diagnosen og ved endringer i forelderens tilstand, behandlingsopplegg eller prognose. En kritisk tid for mange var ved tilbakefall (13, $14,18)$. Tenåringene i en studie satte pris på familiemedlemmer og helsepersonell som var sensitive for deres beredskap til å ta i mot informasjon (18). Kommunikasjon om kreftdiagnosen ble av mange unge sett på som en prosess $(11,18)$. De syntes å fortolke og gi mening til kreftsykdommen etter hvert som de merket dens innvirkning på deres daglige liv. Behovet for informasjon og støtte var større når forelderen ble sykere (18).

\section{Informasjonskilder}

For de fleste var foreldrene deres viktigste informasjonskilde (11, $12,13,18)$. Noen ønsket også å snakke med helsepersonell eller andre utenfor familien $(12,13)$. De satte pris på å kunne stille

spørsmål til noen som hadde kunnskap om sykdommen $(17,18,20)$ og hvordan det er å være i en familie når en av foreldrene har kreft (14). Noen opplevde at informasjon gitt på tomannshånd var lettere å motta og forstå (18). Besøk på

barna ikke turte å fortelle om sine følelser, bekymringer og spørsmål fordi de var redd for å uroe foreldrene, eller usikre på hvordan de skulle gjøre det $(12,13,14)$. Særlig eldre barn og ungdom holdt tilbake egne problemer for å beskytte foreldrene

\section{Mange hadde mer forkunnskaper om kreft enn foreldrene var klar over.}

sykehuset bidro til økt kunnskap og avmystifisering dersom barnet var forberedt og forholdene tilrettelagt $(15,17,21,22)$. Flere ønsket tilgang til skriftlig materiale tilpasset unge $(11,13)$. Bruk av bilder og filmer kunne også være til god hjelp (20). Eldre barn og ungdommer var ofte mer aktive til å søke informasjon på egen hånd, for eksempel på internett, og mange hadde ønsket anbefalinger om pålitelige websider $(11,13,17,20)$. Mange var interessert i hvordan andre taklet situasjonen og ønsket å lære av det (17). Samtalegrupper med jevnaldrende var for mange en kilde til økt kunnskap og forståelse, og en hjelp til å sette ord på egne bekymringer $(14,16,18)$. Det bidro også til økt åpenhet i familien $(14,16)$. Chatteforum ble foretrukket av noen, fordi det ga tilgang til andres erfaringer samtidig som man kunne være anonym (13).

\section{Gjensidig beskyttelse}

Selv om foreldrene hadde tro på åpen kommunikasjon, holdt de ofte tilbake informasjon. Dette gjorde de enten fordi de trodde barna ikke ville forstå, fordi de selv manglet kunnskap, de ville beskytte barna eller de var redd for spørsmål om mulig død $(12,13,19,20,21,22)$. Det viste seg også at mange av
(14). Denne gjensidige beskyttelsen kunne være en barriere for åpen kommunikasjon om emosjonelle temaer i familien (12, $13,14,16)$.

\section{DISKUSJON}

Ut ifra de inkluderte studiene kan man oppsummere resultatene innenfor seks tema. Disse går igjen når barn og foreldre beskriver barnas informasjonsbehov. 1) Barnets forståelse: Ved mangel på informasjon konstruerer barna sine egne forklaringer som kan være preget av misforståelser. 2) Informasjonens innhold: Barna er opptatt av om foreldrene kommer til å overleve. 3) Omfang: Det kan tyde på at barns informasjonsbehov er større ved stigende alder. 4)Timing: Barn ønsker å bli involvert ifra starten når det skjer endringer. 5) Informasjonskilder: Foreldrene er barnas viktigste informasjonskilde. 6) Gjensidig beskyttelse: Foreldre holder tilbake informasjon og barn holder tilbake bekymringer for å beskytte den andre.

I rundskrivet fra Helsedirektoratet (9) står det at barn kan ha behov for: "adekvat informasjon om sykdomssituasjonen til forelderen, forklaring av eventuell diagnose samt forklaring av symptomer, hva som har forårsaket sykdommen eller 
tilstanden, hva slags behandling som gis, hvordan forelderen blir ivaretatt, hvor lenge behandlingen varer, hvordan tilstanden påvirker forelderen, barnet og familiens situasjon, muligheter for besøk og hvordan det skal foregå» (s. 12).

Rundskrivet henviser ikke til forskning, men resultatene fra litteraturgjennomgangen bekrefter og utdyper anbefalingene som her gis. Noe som ikke uttrykkes eksplisitt i rundskrivet, men som studiene avdekker er at barn av kreftpasienter også er opptatt av spørsmål om prognose. Dette kan oppfattes som et uttrykk for barns behov for å være forberedt og kunne ta aktivt del i å planlegge livet sitt. Emerence (ti år) sa det slik $i$ en film produsert av Kreftforeningen; «Jeg har lyst til å vite hvor lenge det er til pappa dør på grunn av at - hvis det er tre år til, da er det ikke sånn at jeg vil være sammen med han veldig ofte, men hvis det er tre måneder, da har jeg lyst til å være med han veldig mye og bry meg om han» (23). Informasjonsønsket kunne likevel være preget av ambivalens ved å søke full åpenhet, og samtidig ville ha forsikring om at alt ville gå bra (13).

I tillegg til informasjon om den syke, sier rundskrivet at barn trenger informasjon om sin egen situasjon (9): «Barnet må vite at det selv blir tatt vare på, og av hvem, hva som er normale reaksjoner hos barn når voksne har et alvorlig helseproblem, at den voksnes tilstand ikke er barnets skyld, at barnet ikke kan hjelpe den syke med å bli frisk, at barnet har lov til å ha det bra og fortsette med aktiviteter som er bra for barnet ... Barnet må få vite hvem som vet om familiens situasjon, og hvem barnet kan snakke med om det som er vanskelig» (s. 12).

Dette korresponderer med resultatene fra litteraturgjennomgangen. Studiene viser imidlertid også at barn av kreftpasienter kan trenge avklaring om egen helserisiko, samt informasjon om hvordan de kan hjelpe $(13,14,18)$. Mange ønsker å være til nytte, men kan være redd for å gjøre feil (19). Det å få bidra kan styrke barnets opplevelse av tilhørighet og kompetanse så sant oppgavene står i forhold til barnets kapasitet (7).

Studiene understreker viktigheten av at informasjonen tilpasses den enkeltes behov. Dette innebærer også respekt for barnets eventuelle ønske om å begrense informasjon $(18,21)$. Hensikten med informasjonen må være å hjelpe barnet til å skape forståelse, mening og forutsigbarhet samt redusere stress og bekymringer (5). «Informasjonsdumping» kan bidra til økt frykt dersom det ikke tas hensyn til barnets beredthet (21). En god regel kan derfor være å informere om helheten først, og detaljene etter hvert i dialog og samspill med barnet. Barnet bør heller ikke ha mer informasjon enn omsorgspersonene fordi det kan være en belastning å være informasjonskilde for andre (9).

Det at barnets oppfatning av sykdommen synes å ha større betydning enn objektive sykdomskarakteristikker (19) taler for å lytte til hva barnet selv tenker om situasjonen, ta utgangspunkt i det og gi tilpasset informasjon ut fra behov, alder og modenhet. Studiene viste imidlertid at kommunikasjon om kreftsykdommen ofte var enveis, og preget av et ensidig fokus på medisinsk informasjon (15). Veiledning kan bidra til at foreldrene også hjelper barna sine til «å forstå seg selv og lære hvordan de kan takle vanskelige og forvirrende følelser, tanker og reaksjoner» (14). De nye lovbestemmelsene pålegger helsepersonell å tilby dette. Derimot gis det ikke anledning til å gå utenom taushetsplikten. Høringssvarene fra fagmiljøene i Norge viser relativt stor enighet om at det ville være uklokt, da det lett kunne virke uheldig inn på samspillet i familien og på tillitsforholdet mellom pasient og helsepersonell (1).

Det er behov for økt systematikk i tilbudet til disse familiene og kompetansehevende tiltak blant helsepersonell. Endringer i Spesialisthelsetjenesteloven ny \$3-7 pålegger helseforetakene å ha barneansvarlig personell som skal ha et særlig ansvar for å koordinere dette arbeidet (9).

Siden dette er kvalitative studier belyser de ulike perspektiv, og til sammen får man en bedre innsikt $\mathrm{i}$ barns og ungdoms informasjonsbehov. Svakheter med denne litteraturstudien kan være at vi bare har med nyere forskning. Det er mulig at det finnes aktuelle studier publisert før 1998. I tillegg kan det være en svakhet at utvelgelsen av de aktuelle studiene bare er gjort av en person. Mange av pasientene i de inkluderte studiene er kvinner med brystkreft, noe som kan representere en skjevhet $\mathrm{i}$ forhold til andre kreftdiagnoser. Studiene har dessuten relativt få informanter, og de sier lite om de minste barnas informasjonsbehov $(<6$ år). Funnene kan således ikke regnes som overførbare til alle barn med kreftsyke foreldre. Allikevel kan de gi verdifull innsikt $\mathrm{i}$ informasjonsbehov hos barn og ungdom. Alle studiene er utført i vestlige land, og videre 
forkning bør også inkludere barn fra andre kulturer, særlig med tanke på et økende flerkulturelt samfunn.

\section{KONKLUSJON}

Litteraturgjennomgangen tyder på at barn av kreftpasienter har behov for ærlig og konk- ret informasjon om sykdom og behandling, samt hvordan dette vil påvirke hverdagslivet og fremtiden. Foreldrene er barnas viktigste informasjonskilde. Dette er viktig kunnskap for helsepersonell slik at de kan bistå foreldre i å ivareta informasjonsbehovet hos sine barn.
Vi vil gjerne fà takke styringsgruppen for implementering av kunnskapsbasert praksis ved Oslo Universitetssykehus Radiumbospitalet ved leder Marie Bruheim og prosjektgruppen ved Kjersti Stokke for à ha initiert og lagt til rette for dette arbeidet.

\section{LITTERATUR}

1. Det Kongelege Helse- og Omsorgsdepartement. Ot.prp. nr. 84 (20082009). Om lov om endringar i helsepersonelloven m.m. loppfølging av born som pårørande) 2009

2. Rosbjerg RS, Thastum M. Psykologisk trivsel hos børn af forældre med kræft. En oversigt over forskning. Omsorg 2005;22: 7-12.

3. Værholm R. Informasjon til barn og unge i sorg relatert til foreldrenes kreftdiagnose. Omsorg 2005;22(4): 49-52.

4. Bugge KE. Hvordan støtte familier sorg? I: Kirkevold M og Ekern KS. (red). Familien i sykepleiefaget. Oslo: Gyldendal, 2001:87-107.

5. Benner P, Wrubel J. The primacy of caring. Stress and Coping in Health and Illness. California: Addison-Wesley Publishing Company, 1989

6. Dyregrov A. Barn og traumer. Bergen: Sigma forlag. 1998.

7. Sommerschild H. Mestring som styrende begrep. I: Gjærum B, Grøholt B, Sommerschild H. (red). Mestring som mulighet i møte med barn, ungdom og foreldre. Oslo: Tano Aschehoug, 1998.

8. Det Kongelige Helse- og Omsorgsdepartement. «Forslag til endring av Helsepersonelloven mv. for å styrke rettsstillingen til barn av foreldre med psykisk sykdom, rusmiddelavhengighet eller alvorlig somatisk sykdom eller skade». Høringsnotat fra Helse- og
Omsorgedepartementet, 2008

9. Helsedirektoratet. Rundskriv. Barn som pårørende. Oslo, 2010. www.shdir.no 10. Helseth S, Slettebø A. Research involving Children: Some ethical issues. Nursing Ethics 2004:11:298-308.

11. Finch A, Gibson F. How do young people find out about their parent's cancer diagnosis: A phenomenological study. European Journal of Oncology Nursing 2009;13:213-22

12. Forrest G, Plumb C, Ziebland S, Stein A. Breast cancer in young families: a qualitative interview study of fathers and their role and communication with their children following the diagnosis of maternal breastcancer. Psycho-Oncology 2009;18:96-103.

13. Kennedy VL, Lloyd-Williams M. Information and communication when a parent has advanced cancer. Journal of Affective disorders 2008:114:149-55. 14. Bugge KE, Helseth S, Darbyshire $\mathrm{Ph}$. Children's experiences of a family support program when their parent has incurable cancer. Cancer Nursing 2008;31(6): 426-34.

15. Thastum M, Johansen MB, Gubba $L$, Olesen BL, Romer G. Coping, social relations and communication: A qualitative exploratory study of children of parents with cancer. Clinical Child Psychology and Psychiatry 2008;13(1): 123-38

16. Ensby T, Dyregrov K, Landmark B. $\AA$ treffe andre som virkelig forstår. Syke- pleien Forskning 2008;3:118-27.

17. Forrest G, Plumb C, Ziebland S, Stein A. Breast cancer in the family children's perceptions of Their mother's cancer and its initial treatment; qualitative study. BMJ 2006:332:998-1003. 18. Kristjanson LJ, Chalmers KI, Woodgate R. Information and support needs of adolescent children of women with breastcancer. Oncology Nursing Forum 2004; 31: 111-19

19. Visser A, Huizinga GA, van der Graaf WTA, Hoekstra HJ, Hoekstra-Weebers JEHM. The impact of parental cancer in children and the family: A review of the literature. Cancer Treatment reviews 2004:30:683-94.

20. Hilton A, Gustavson K. Shielding and being shielded: Children's perspective oncoping with their mother's cancer and chemotherapy. Can Oncol Nurs J 2002:2:198-206.

21. Shands ME, Lewis FM, Zahlis EH. Mother and child interactions about the mother's breast cancer: An interview study. Oncology Nursing Forum 2000;27:77-85

22. Barnes J, Kroll L, Bruke O, Lee J, Jones A, Stein A. Qualitaive interview study of communication between parents and children about maternal breast cancer. Western Journal of medicine 2000; 173(6): 385-88

23. Grønnsdal EG. Min far er på video når noen i familien er syk av kreft. En film for og av barn. Kreftforeningen 2005. 